\title{
The Regional Analysis of Beef Cattle Farm Development in Semarang Regency
}

\author{
B. Santoso ${ }^{a}$ \& B. W. H. E. Prasetiyono ${ }^{b, *}$ \\ ${ }^{a}$ Master Program in Environmental Science, Diponegoro University \\ ${ }^{b}$ Faculty of Animal and Agricultural Sciences, Diponegoro University \\ Jl. Prof. Soedarto, Kampus Tembalang Semarang 50275, Indonesia \\ *Corresponding author: bambangwhep63@gmail.com \\ (Received 10-06-2019; Revised 20-09-2019; Accepted 23-09-2019)
}

\begin{abstract}
One of the reasons for the low production and productivity of beef cattle in Indonesia is that information on the allocation of livestock areas development is not yet clear. This study aimed to determine the priority areas for developing beef cattle farm in Semarang Regency based on the concept of sustainability. Sustainability was analyzed through the determination of leading commodities (analysis of Location Quotient and Shift Share), optimization of regional potential (analysis of carrying capacity and carrying capacity index of forage, and assessment of suitability of ecological environment of beef cattle). The process of spatial analysis used GIS software. Comprehensive planning for the development of beef cattle farm was directed in three sub-districts, namely: Bringin, Bancak, and Banyubiru. The results of the analysis showed that the three subdistricts were beef cattle base areas ( $L Q>1$ ), had business growth (positive SS), and had a safe status for forage availability (>2). Other results showed that the carrying capacity for beef cattle farms in Bringin sub-district was 15,829 AU, Bancak was 8,457 AU, and Banyubiru was 6,315 $\mathrm{AU}$. The land area suitable for beef cattle farm from the three priority sub-districts was $5,760.141 \mathrm{Ha}$. It can be concluded that the development of beef cattle farm in Semarang Regency is focused on three priority subdistricts, namely: Bringin, Bancak, and Banyubiru. The results of this study can be an input for local governments in determining the direction and pattern of beef cattle farm development to be more sustainable.
\end{abstract}

Keywords: beef cattle; regional analysis; sustainability of livestock sector

\section{INTRODUCTION}

The directed and sustainable development of the livestock sector is believed to be able to contribute positively to regional development. Along with the increase in population, there is an increasing demand for food from animal protein, such as beef. Beef consumption in developing countries such as in Indonesia tends to increase every year (Thornton, 2010; Agus \& Widi, 2018), however the population of beef cattle in some regions actually decreases due to the complexity of technical and non-technical problems (Paly et al., 2013; Ariningsih, 2014; Nuhung, 2015). There is a gap between demand and supply of beef products, which is increasingly widening. Many factors causing this gap, including the domestic production of beef cattle is still low because information on the allocation of livestock development areas is not yet clear.

Cattle farmings in Indonesia are categorized as unsustainable (Syarifuddin, 2009; Sutanto \& Hendraningsih, 2011). The number of available beef cattle has not been able to meet the high meat consumption of people. The consumption of beef in 2020 is estimated to reach $3.36 \mathrm{~kg}$ per capita per year, but beef production is still not able to fulfill it; there is a deficit in beef supply by 198,350 tons (Kementan, 2016; Agus \& Widi, 2018). Most of the beef production in Indonesia, $78 \%$ comes from traditional livestock, $5 \%$ from imports, and $17 \%$ from live livestock imports, especially from Australia (Zakiah et al., 2017). Imports of beef are indeed relatively larger compared to the other types of meat imports, contributing $21.44 \%$ to the total import value of livestock, while the import value of livestock is $18.29 \%$ of the total value of agricultural imports nationally (Rouf et al., 2014).

Policy efforts to reduce beef imports must be studied, by strengthening domestic production that is beneficial for farmers (Pasandaran et al., 2014). The development of beef cattle farms in potential areas is an effort to strengthen meat production in the country so that the implementation must be carried out with a comprehensive assessment. Semarang Regency is a region in Central Java Province that has the potential to develop beef cattle farms because it has natural resources in the form of land as a place for livestock keeping and forage production. Good quality and forage availability can increase production, especially for increasing body weight of cattle (Suhaema et al., 2014). Forage producing areas in Semarang Regency include gardens $(25,562.04 \mathrm{Ha})$, rice fields $(23,745.96 \mathrm{Ha})$, and forests $(6,032.77 \mathrm{Ha})$. The 
beef cattle population in this region during the 20142016 period continued to decline, ranging from 53,135; 49,172; and 46,238 (BPS Kabupaten Semarang, 2018).

The development of beef cattle farms in Semarang Regency needs to adopt the concept of sustainability. The concept of sustainability is the achievement of economic, environmental, and social goals simultaneously which is represented by various performance indicators (Darnhofer et al., 2010). Sustainability is also defined as the concept of multidimensional (economic, ecological, and social) and multiscale (micro, meso, and macro), although in its application, it is often limited to one particular aspect (Santos et al., 2017). Economic sustainability is closely related to the value of comparative and competitive advantages of certain commodities (Broom et al., 2013; Sabaghi et al., 2016), while environmental sustainability includes optimizing the availability and efficient use of natural resources (Atanga et al., 2013).

The sustainability of beef cattle farms can be identified through a regional approach, by considering the existence of leading commodities and the potential of the region concerned (Mulyono \& Munibah, 2016; Parmawati et al., 2018). Determination of leading commodities characterized by the existence of comparative and competitive advantages is the first step towards the efficient development of livestock sector. The potential of the region to support the development of beef cattle farms is determined by optimizing the carrying capacity and carrying capacity index of forage, as well as by assessing the suitability of the land where the livestocks are raised. Land suitability for beef cattle farms with intensive production systems considers several environmental factors that affect the growth of these cattle.

Mapping activities based on the determination of leading commodities and optimization of regional potential are needed as a basis for planning sustainable development of beef cattle farms. This study aims to determine the priority areas for developing beef cattle farms in Semarang Regency. The results of this study are expected to be one of the considerations in determining the direction and development policy of the beef cattle farms sector in Semarang Regency.

\section{MATERIALS AND METHODS}

This research was a type of quantitative research and applied the concept of sustainability. Sustainabilities assessed were economic and environmental sustainabilities for beef cattle farm in Semarang Regency. Economic sustainability was identified through the determination of the leading commodity of livestock, while environmental sustainability was identified through the calculation of the carrying capacity and carrying capacity index of forage, and the assessment of suitability of ecological environment of beef cattle. In detail, each step of the analysis was outlined below.

\section{Leading Commodity}

Determination of leading livestock commodities in an area used Location Quotient (LQ) and Shift Share
(SS) analysis. The rationale for the two methods was the economic basis theory. LQ analysis was relatively simple, but the benefits were large enough for the initial identification of the ability of a sector in regional development. The shift in the structure of economic activity in beef cattle business, whether experiencing growth or decline was analyzed using Shift Share (SS). SS analysis can be used to see the growth of the economic sectors of a region for two-time points (Muta'ali, 2015). LQ and SS analysis used the following equations (Ciptayasa et al., 2016; Mulyono \& Munibah, 2016). $\mathrm{LQ}_{\mathrm{ij}}=(\mathrm{Xij} / \mathrm{Xi}) /.(\mathrm{X} . \mathrm{j} / \mathrm{X} .$.$) (Equation 1)$

where $X_{\mathrm{ij}}$ is Beef cattle population in the sub-district $A, X_{i}$. is Population of all types of livestock in the subdistrict $A, X_{. j}$ is Beef cattle population in Semarang Regency, and $X$ is Population of all types of livestock in Semarang Regency).

$\mathrm{SS}=[(\mathrm{X} . .(\mathrm{t} 1)) /(\mathrm{X} . .(\mathrm{t} 0))-1]+[(\mathrm{X} . \mathrm{i}(\mathrm{t} 1)) /(\mathrm{X} . \mathrm{i}(\mathrm{t} 0))-(\mathrm{X} . .(\mathrm{t} 1)) /(\mathrm{X} .$. $(\mathrm{t} 0))]+[(\mathrm{Xij}(\mathrm{t} 1)) /(\mathrm{Xij}(\mathrm{t} 0))-(\mathrm{X} . \mathrm{i}(\mathrm{t} 1)) /(\mathrm{X} . \mathrm{i}((\mathrm{t} 0))]$

(Equation 2)

(Regional share, Proportional shift, Differential shift, $X$. is Population of all types of livestock in Semarang Regency, $\mathrm{X}_{\mathrm{i}}$ is Beef cattle population in Semarang Regency, Xij is Beef cattle population in sub-district A, t0 is Early 2013 year point, and t1 is End of year 2017).

\section{Carrying Capacity and Carrying Capacity Index of Forage}

The carrying capacity of the region for livestock development is indicated by the ability of the region to produce forage that can accommodate and meet the needs of a number of beef cattle populations. Forages were divided into two types, namely fresh forage (grass, legume) and dry forage (straw). An assessment of the carrying capacity index of forage was conducted to assess the availability of animal feed in a region, whether it was classified as safe, vulnerable, critical, or very critical.

The carrying capacity of beef cattle farms was calculated based on the production of forage dry matter against the minimum feed requirements of cattle (1 $A U)$ in one year. The animal unit (AU) was a unit for the ruminant livestock population multiplied by the conversion factor. The conversion factor for beef cattle was 0,7 (Muta'ali, 2015; Saputra et al., 2016). Forage dry matter production was the amount of potential agricultural waste and natural forage potential, using equations that refer to Suhaema et al. (2014) and Yuniar et al. (2016).

Potential of agricultural waste (ton) $=$

$\{(\mathrm{wr} \times 0.4)+(\mathrm{fr} \times 3 \times 0.4)+(\mathrm{cn} \times 3 \times 0.5)+(\mathrm{sb} \times 3 \times 0.55)+$ $(p t \times 2 \times 0.55)+(\operatorname{sp} \times 0.25 / 6)+(\operatorname{cs} \times 0.25 / 4)\} \times 0.65$

where wr is wetland rice, fr is field rice, $\mathrm{cn}$ is corn, sb is soybean, pt is peanuts, sp is sweet potatoes, cs is cassava. The numbers in the formula are assumptions about the potential waste produced from the production of each type of plant food. 
Natural forage potential (ton) $=$

$\{(\mathrm{Ga} \times 2.875)+(\mathrm{Fa} \times 0.6)+(\mathrm{Cpa} \times 10)+(\mathrm{Cfa} \times 0.5)+(\mathrm{Cla}$ $\times 5)\} \times 0.5$

where $\mathrm{Ga}$ is garden area, $\mathrm{Fa}$ is forest area, $\mathrm{Cpa}$ is coconut plant area, Cfa is coffee plant area, $\mathrm{Cla}$ is clove plant area. The numbers in the formula are assumed to be natural forage potential produced per hectare of land use area.

Minimum cattle feed requirements $(R)=$

$2.5 \% \times 50 \% \times 365 \times 400 \mathrm{~kg}=1.82$ ton DDM/year/AU (Equation 3)

where $R$ is minimum cattle feed requirements (1 AU) in tons of digestible dry matter for 1 year, $2.5 \%$ is minimum requirement for the number of forage rations (dry matter) on livestock weight, $50 \%$ is average value digestibility power of various types of plants, 365 is number of days in 1 year, $400 \mathrm{~kg}$ is live weight of $1 \mathrm{AU}$ of beef cattle in Semarang Regency. Equations that refer to Suhaema et al. (2014) and Yuniar et al. (2016).

The results of the calculation of forage dry matter production were then used to determine the carrying capacity of beef cattle farms using the following equations (Suhaema et al., 2014; Yuniar et al., 2016).

$\mathrm{CC}(\mathrm{AU})=$ Forage dry matter production (tons of DDM/ year) / Minimum cattle feed requirement (tons of DDM/year/AU)

(Equation 4)

The level of animal feed security in a region was measured by forage carrying capacity index. Carrying capacity index values were values that indicated the status of the availability of forage for beef cattle, namely: very critical $(\leq 1)$, critical $(>1-1.5)$, vulnerable $(>1.5-2)$, and safe $(>2)$.

Forage carrying capacity index=

Carrying capacity (AU) / Amount of beef cattle population in 2017 (AU) (Equation 5)

\section{Suitability of the Ecological Environment of Beef Cattle}

The research sample for the assessment of the suitability ecological environment of beef cattle farms in Semarang Regency was 19 points spreading throughout the sub-district area (Table 5). The determination of the sample was using purposive sampling technique. The purposive sampling technique was also called judgment sampling (Tongco, 2007), which was used to determine the sample based on research considerations. In each sub-district, one village was taken which had the most beef cattle population.

Lands available for the development of beef cattle farms are gardens, grasslands, open land, rice fields, and dryland agriculture. The fields are assumed to be able to be used for building housing for beef cattle. The assessment of land suitable for beef cattle farming with intensive maintenance patterns also takes into account several environmental parameters that influence the growth of livestock.

Land suitability assessment for beef cattle farms began by making a map of land units. Maps of beef cattle land units referred to research of Rusmana et al. (2006) which stated that there were four maps needed for overlaying, namely: land type maps, agro-climate maps, regional altitude maps, and slope maps. The final step was to make a "suitability map of the ecological environment of beef cattle". The method used was by overlaying between land unit maps with environmental parameters that affected the growth of beef cattle (Table 1). Land suitability was classified into 4 levels or strata, namely: very suitable (S-1), quite suitable (S-2), according to marginal (S-3), and non-suitable (NS) (Rusmana et al., 2006; Suhaema et al., 2014; Yuniar et al., 2016). The entire process was created and analyzed using GIS software.

\section{RESULTS}

\section{Leading Commodity}

The leading commodity of livestock in an area was determined based on comparative advantage (location quotient analysis) and competitive advantage (shiftshare analysis). Beef cattle commodities that had LQ $>1$ and SS (+) values were the leading commodities in the region. The interpretation of the value of $L Q>1$, was a base or leading sector, beef cattle products (meat) were able to meet markets inside and outside the region. The value of $L Q<1$ implied a non-base sector, livestock products had not been able to meet markets inside and outside the region. The value of $L Q=1$ implied that the sector was balanced with the reference region, livestock products were only able to meet markets in the area. The basis for calculating LQ analysis for livestock commodities was livestock population data (Hendayana, 2003). Data bias in calculations could be minimized by using a minimum 5 year data series (Table 2).

Shift share analysis started from the basic assumption that economic growth or added value of an activity in a particular region was influenced by three main components which were interconnected with each other, namely: regional growth, sectoral growth, and growth in share or regional competitiveness (Ciptayasa et al., 2016). Through these three components, it could be seen which elements had encouraged regional economic

Table 1. Environmental parameters that influence the growth of beef cattle with intensive maintenance patterns

\begin{tabular}{|c|c|c|}
\hline \multirow[t]{2}{*}{ Parameter } & \multicolumn{2}{|c|}{$\begin{array}{l}\text { Order of environmental } \\
\text { suitability of beef cattle }\end{array}$} \\
\hline & S (Suitable) & $\mathrm{N}$ (Unsuitable) \\
\hline $\begin{array}{l}\text { Temperature Humidity Index } \\
\text { (THI) }\end{array}$ & $70-80$ & $<70,>80$ \\
\hline \multicolumn{3}{|l|}{ Water availability $(w)$} \\
\hline $\begin{array}{l}\text { Dry month }(<100 \mathrm{~mm} \\
\text { rainfall/month) }\end{array}$ & $<8$ months & $>8$ months \\
\hline Rainfall/year (mm) & $<4,000$ & $>4,000$ \\
\hline $\begin{array}{l}\text { The existence of a water } \\
\text { source }\end{array}$ & Available & Not Available \\
\hline \multicolumn{3}{|l|}{ Water quality (q) } \\
\hline $\mathrm{pH}$ water & $6.5-9.0$ & $<6.5 ;>9.0$ \\
\hline Slope (\%) & $<40$ & $>40$ \\
\hline
\end{tabular}

Source: (Suhaema et al., 2014; Yuniar et al., 2016). 
growth. The value of each component could be positive or negative, but the total number (shift-share) would always be positive if the regional economic growth were positive, and vice versa.

The results of the LQ and SS analysis calculations for beef cattle commodities in Semarang Regency are shown in Table 3. Based on the results of the analysis conducted, the subdistrict areas becoming the beef cattle base sector (LQ> 1) were Bancak (4.93), Banyubiru (3.97), Ambarawa (3.92), Bringin (2.82), and Bawen (2.34). Beef cattle keeping was concentrated in these areas or in the other words the economic density of beef cattle was higher than that of in the other regions.
Beef cattle commodities that had competitive advantages were seen based on positive shift-share (SS) values. Sub-districts with a positive SS value means experiencing growth (competitiveness) related to keeping beef cattle. On the other hand, sub-districts with negative SS value means that the area is not growing (stagnant) and can even experience setbacks. The results of the analysis conducted in Table 3 showed that subdistricts with positive SS values were in West Ungaran (1.286), Banyubiru (0.47), Pabelan (0.435), Bandungan (0.203), Bancak (0.077), Bringin (0.039), and Tengaran (0.026).

Table 2. Growth of livestock populations in Semarang Regency (heads)

\begin{tabular}{|c|c|c|c|c|c|}
\hline \multirow{2}{*}{ Type of livestock } & \multicolumn{5}{|c|}{ Year } \\
\hline & 2013 & 2014 & 2015 & 2016 & 2017 \\
\hline Pig & 32,640 & 17,300 & 18,431 & 15,971 & 15,850 \\
\hline Goat & 197,029 & 136,999 & 123,294 & 117,003 & 117,373 \\
\hline Sheep & 290,764 & 191,346 & 172,211 & 167,374 & 162,694 \\
\hline Rabbit & 20,352 & 9,375 & 10,462 & 11,629 & 11,916 \\
\hline Horse & 1,711 & 497 & 515 & 524 & 581 \\
\hline Beef cattle & 51,901 & 53,135 & 49,172 & 46,238 & 48,444 \\
\hline Dairy cows & 22,308 & 27,609 & 25,780 & 25,690 & 25,557 \\
\hline Buffalo & 2,941 & 3,168 & 2,614 & 2,629 & 2,589 \\
\hline Laying chicken & $1,821,286$ & $1,813,049$ & $1,452,019$ & $1,331,528$ & $1,572,463$ \\
\hline Broiler chicken & $12,046,319$ & $7,501,700$ & $10,144,846$ & $10,754,602$ & $11,812,311$ \\
\hline Chicken breed & 819,067 & 860,408 & 818,568 & 861,989 & 823,226 \\
\hline Duck & 206,882 & 92,963 & 80,801 & 127,859 & 125,261 \\
\hline Quail & 122,200 & 238,930 & 227,737 & 176,730 & 142,856 \\
\hline Muscovy duck & 102,966 & 72,227 & 63,889 & 61,963 & 54,402 \\
\hline
\end{tabular}

Source: (BPS Kabupaten Semarang, 2018).

Table 3. Value of LQ and SS of beef cattle in Semarang Regency in 2018

\begin{tabular}{|c|c|c|c|c|c|c|}
\hline No & Sub-district & LQ & RS & PS & DF & SS \\
\hline 1 & Getasan & 0.63 & -0.052 & -0.014 & -0.359 & -0.425 \\
\hline 2 & Tengaran & 0.55 & -0.052 & -0.014 & 0.092 & 0.026 \\
\hline 3 & Susukan & 1.11 & -0.052 & -0.014 & -0.137 & -0.203 \\
\hline 4 & Kaliwungu & 1.22 & -0.052 & -0.014 & 0.048 & -0.018 \\
\hline 5 & Suruh & 0.88 & -0.052 & -0.014 & -0.213 & -0.279 \\
\hline 6 & Pabelan & 1.75 & -0.052 & -0.014 & 0.501 & 0.435 \\
\hline 7 & Tuntang & 0.28 & -0.052 & -0.014 & -0.689 & -0.755 \\
\hline 8 & Banyubiru & 3.97 & -0.052 & -0.014 & 0.536 & 0.47 \\
\hline 9 & Jambu & 0.42 & -0.052 & -0.014 & -0.417 & -0.483 \\
\hline 10 & Sumowono & 0.95 & -0.052 & -0.014 & -0.234 & -0.3 \\
\hline 11 & Ambarawa & 3.92 & -0.052 & -0.014 & 0.006 & -0.06 \\
\hline 12 & Bandungan & 1.01 & -0.052 & -0.014 & 0.269 & 0.203 \\
\hline 13 & Bawen & 2.34 & -0.052 & -0.014 & 0.0009 & -0.0651 \\
\hline 14 & Bringin & 2.82 & -0.052 & -0.014 & 0.105 & 0.039 \\
\hline 15 & Bancak & 4.93 & -0.052 & -0.014 & 0.143 & 0.077 \\
\hline 16 & Pringapus & 1.38 & -0.052 & -0.014 & -0.312 & -0.378 \\
\hline 17 & Bergas & 0.77 & -0.052 & -0.014 & -0.106 & -0.172 \\
\hline 18 & West Ungaran & 0.77 & -0.052 & -0.014 & 1.352 & 1.286 \\
\hline 19 & East Ungaran & 0.30 & -0.052 & -0.014 & -0.62 & -0.686 \\
\hline
\end{tabular}

Note: $\mathrm{LQ}=$ Location quotient, $\mathrm{SS}=$ Shift share, $\mathrm{RS}=$ Regional share, $\mathrm{PS}=$ Proportional shift, DS= Differential shift. 
The development of beef cattle farms in Semarang Regency is prioritized in the sub-districts with $\mathrm{LQ}>1$ and SS (+) values. The sub-districts are Bringin, Bancak, and Banyubiru.

\section{Carrying Capacity and Carrying Capacity Index of Forage}

The potential availability of feed for beef cattle was seen based on the amount of forage dry matter production (tons of DDM) that could be produced by the region concerned. Dry matter is the total feed ingredients without water content, which can come from forages. The region with the largest forage dry matter production has the highest carrying capacity for the development of beef cattle farms, and vice versa. Forage is one of the production inputs that determine the success of livestock business because it directly affects productivity and efficiency (Yuniar et al., 2016). Table 4 shows the calculation of carrying capacity and carrying capacity index of forage for beef cattle farms in Semarang Regency.

Based on the results of the analysis conducted in Table 4, it was known that there were three sub-districts with the highest production of forage dry matter, namely Bringin (28,808.63 tons DDM), Pringapus (23,509.36 tons DDM), and Suruh $(19,522.03$ tons DDM). Subdistrict area with the lowest forage dry matter production was Bandungan (4,327.55 tons DDM). The status of the availability of forage in Bandungan sub-district was categorized as very critical (0.82), while in Tengaran sub-district it was categorized as vulnerable (1.69).
Therefore, these two sub-districts are not recommended for the development of beef cattle farms. Sub-district areas with carrying capacity index value $>2$ (safe) means that the areas can be recommended for the development of beef cattle farms. The advantage obtained by the area with this safe category is that farmers can reduce the amount of production costs for beef cattle feed.

Semarang Regency had a carrying capacity for beef cattle farms of $122,725 \mathrm{AU}$. The population of beef cattle in 2017 was 33,911 AU, so the Semarang Regency area was assumed to still be able to accommodate 88,814 AU beef cattle in 2018 .

\section{The Suitability of Ecological Environment of Beef Cattle}

The results of field measurements and secondary data collection conducted on several environmental factors that influence the growth of beef cattle are shown in Table 5. The factors that limited the assessment of the suitability of the ecological environment of beef cattle farming in Semarang Regency were the Temperature Humidity Index (THI) and water $\mathrm{pH}$. Annual rainfall $(<4000 \mathrm{~mm})$ and dry months $(<8)$ were in the appropriate category.

The suitability of the ecological environment map for beef cattle farms in Semarang Regency is shown in Figure 1. The white area was an area that was not assessed because it was designated as land for settlements, plantations, tourism, and forests. Based on data in Figure 1, the level of suitability of the produced beef

Table 4. Carrying capacity and carrying capacity index of forage in Semarang Regency in 2018

\begin{tabular}{|c|c|c|c|c|c|c|c|c|}
\hline SD & Вср 2017 & $\begin{array}{c}\text { Вср } 2017 \\
\text { (AU) }\end{array}$ & $\mathrm{Rm}$ & $\mathrm{R} B \mathrm{C}$ & F Dmp & $\mathrm{CC}$ & $\mathrm{CCI}$ & AV \\
\hline A & $\mathrm{b}$ & $\mathrm{c}$ & $\mathrm{d}$ & $e=c \times d$ & $\mathrm{f}$ & $\mathrm{g}=\mathrm{f} / \mathrm{d}$ & $h=g / c$ & \\
\hline Getasan & 2,085 & $1,459.5$ & 1.82 & $2,656.29$ & $7,802.45$ & $4,287.1$ & 2.94 & S \\
\hline Tengaran & 4,881 & $3,416.7$ & 1.82 & $6,218.39$ & $10,526.78$ & $5,783.9$ & 1.69 & $\mathrm{~V}$ \\
\hline Susukan & 2,905 & $2,033.5$ & 1.82 & $3,700.97$ & $15,301.29$ & $8,407.3$ & 4.13 & S \\
\hline Kaliwungu & 4,650 & 3,255 & 1.82 & $5,924.10$ & $13,231.72$ & 7,270.2 & 2.23 & S \\
\hline Suruh & 3,335 & $2,334.5$ & 1.82 & $4,248.79$ & $19,522.03$ & $10,726.4$ & 4.59 & S \\
\hline Pabelan & 4,251 & $2,975.7$ & 1.82 & $5,415.77$ & $12,690.04$ & $6,972.5$ & 2.34 & $S$ \\
\hline Tuntang & 211 & 147.7 & 1.82 & 268.81 & $9,458.60$ & $5,197.03$ & 35.19 & $S$ \\
\hline Banyubiru & 3,840 & $2,688.0$ & 1.82 & $4,892.16$ & $11,493.54$ & 6,315.1 & 2.35 & $S$ \\
\hline Jambu & 741 & 518.7 & 1.82 & 944.03 & $8,816.47$ & $4,844.2$ & 9.34 & S \\
\hline Sumowono & 2,228 & $1,559.6$ & 1.82 & $2,838.47$ & $10,921.51$ & $6,000.8$ & 3.85 & S \\
\hline Ambarawa & 1,661 & $1,162.7$ & 1.82 & $2,116.11$ & 4,935.95 & $2,712.05$ & 2.33 & $\mathrm{~S}$ \\
\hline Bandungan & 4,140 & 2,898 & 1.82 & $5,274.36$ & $4,327.55$ & 2,377.8 & 0.82 & VC \\
\hline Bawen & 2,717 & $1,901.9$ & 1.82 & $3,461.46$ & $7,241.14$ & $3,978.6$ & 2.09 & S \\
\hline Bringin & 2,349 & $1,644.3$ & 1.82 & $2,992.63$ & $28,808.63$ & $15,828.9$ & 9.63 & S \\
\hline Bancak & 2,820 & 1,974 & 1.82 & $3,592.68$ & $15,391.55$ & $8,456.9$ & 4.28 & S \\
\hline Pringapus & 1,333 & 933.1 & 1.82 & $1,698.24$ & $23,509.36$ & $12,917.2$ & 13.84 & $S$ \\
\hline Bergas & 1,828 & $1,279.6$ & 1.82 & $2,328.87$ & $7,593.47$ & $4,172.2$ & 3.26 & S \\
\hline West Ungaran & 2,105 & $1,473.5$ & 1.82 & $2,681.77$ & $5,400.34$ & $2,967.2$ & 2.01 & S \\
\hline East Ungaran & 364 & 254.8 & 1.82 & 463.74 & 6,387.01 & $3,509.3$ & 13.77 & $S$ \\
\hline Total & 48,444 & $33,910.8$ & & $61,717.64$ & $223,359.43$ & $122,724.7$ & 120.68 & \\
\hline
\end{tabular}

Note: $\mathrm{SD}=$ sub-district, $\mathrm{Bcp}=$ beef cattle population, $\mathrm{Bcp}(\mathrm{AU})=$ beef cattle population in livestock units, Rm= minimum feed requirements for beef cattle (ton DDM /year /AU), R bc= beef cattle feed requirements (tons /DDM/year), F Dmp= forage dry matter production (ton DDM), CC= carrying capacity $(\mathrm{AU}), \mathrm{CCI}=$ carrying capacity index of forage, $\mathrm{AV}=$ forage availability status; $\mathrm{S}=\mathrm{safe}, \mathrm{V}=$ vurnerable, $\mathrm{VC}=$ very critical. 
Table 5. Results of measurements of environmental factors that influence the growth of beef cattle in Semarang Regency in 2018

\begin{tabular}{llccccccc}
\hline \multicolumn{1}{c}{ Subdistrict } & Sample (Village) & $\begin{array}{c}\text { Temperature } \\
\left({ }^{\circ} \mathrm{C}\right)\end{array}$ & $\begin{array}{c}\text { Temperature } \\
\left({ }^{\circ} \mathrm{F}\right)\end{array}$ & $\begin{array}{c}\text { Humidity } \\
(\%)\end{array}$ & THI & $\begin{array}{c}\text { Rainfall } \\
(\mathrm{mm} / \text { year })\end{array}$ & $\begin{array}{c}\text { Dry } \\
\text { months }\end{array}$ & $\begin{array}{c}\text { Water } \\
\mathrm{pH}\end{array}$ \\
\hline Getasan & Samirono & 31 & 87.8 & 51 & 79.77 & 3,403 & 3 & 7 \\
Tengaran & Duren & 30 & 86 & 65 & 80.61 & 2,591 & 3 & 5.8 \\
Susukan & Timpik & 32 & 89.6 & 57 & 82.13 & 2,618 & 3 & 6.5 \\
Kaliwungu & Mukiran & 32 & 89.6 & 56 & 81.95 & 2,618 & 0 & 5.5 \\
Suruh & Dadapayam & 32 & 89.6 & 65 & 83.52 & 2,680 & 4 & 6.3 \\
Pabelan & Terban & 32 & 89.6 & 58 & 82.3 & 1,927 & 4 & 6.5 \\
Tuntang & Tlumpakan & 35 & 95 & 46 & 84.01 & 2,676 & 0 & 7 \\
Banyubiru & Wirogomo & 30 & 86 & 51 & 78.45 & 2,066 & 3 & 8 \\
Jambu & Genting & 31 & 87.8 & 49 & 79.44 & 2,489 & 0 & 6.2 \\
Sumowono & Candi Garon & 28 & 82.4 & 58 & 76.76 & 1,383 & 4 & 6.3 \\
Ambarawa & Pasekan & 30 & 86 & 51 & 78.45 & 1,291 & 3 & 6.8 \\
Bandungan & Candi & 29 & 84.2 & 54 & 77.57 & 1,291 & 0 & 6.7 \\
Bawen & Polosiri & 35 & 95 & 49 & 84.62 & 2,061 & 4 & 6.1 \\
Bringin & Banding & 35 & 95 & 54 & 85.64 & 2,211 & 3 & 7.9 \\
Bancak & Pucung & 33 & 91.4 & 58 & 83.68 & 2,091 & 0 & 6.5 \\
Pringapus & Penawangan & 32 & 89.6 & 56 & 81.95 & 2,290 & 3 \\
Bergas & Munding & 32 & 89.6 & 48 & 80.56 & 3,802 & 2 \\
West Ungaran & Gogik & 32 & 89.6 & 49 & 80.74 & 3,316 & 0 & 4 \\
East Ungaran & Kawengen & 33 & 91.4 & 51 & 82.4 & 3,316 & 0 & 7.9 \\
\hline
\end{tabular}

Note: $\mathrm{THI}=\mathrm{T}-\{0.55(1-\mathrm{RH} / 100)(\mathrm{T}-58)\}$, where $\mathrm{T}=$ temperature $\left({ }^{\circ} \mathrm{F}\right), \mathrm{RH}=$ relative humidity .

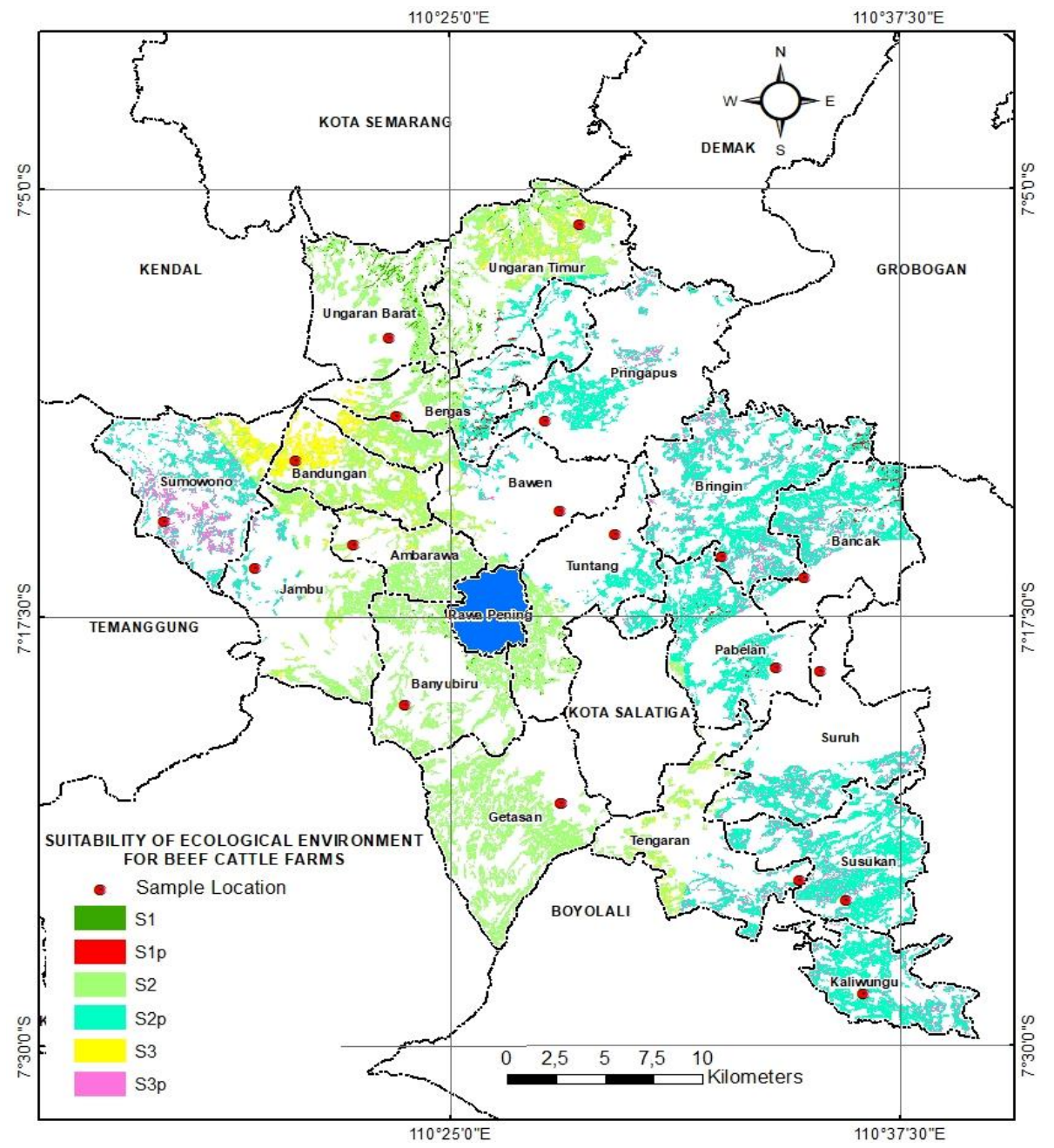

Figure 2. The suitability of ecological environment map for beef cattle farms in Semarang Regency 
cattle ecological environment was: very suitable (S-1), quite suitable (S-2), and according to marginal (S-3). Non-suitable (NS) categories were not assessed because the area had a slope $>40 \%$ (steep - very steep).

The symbol " $\mathrm{p}$ " indicated that there was a limiting factor in the area assessed. The limiting factors were the Temperature Humidity Index (THI) and the $\mathrm{pH}$ of the water for beef cattle consumption (Table 5). Semarang Regency consists of 19 sub-districts. The development of beef cattle farms will be prioritized in sub-districts having $L Q>1$, positive SS (+) value, and carrying capacity index of forage $>2$, namely Bringin, Bancak, and Banyubiru. Banyubiru sub-district was not constrained by the limiting factors, while Bringin and Bancak were constrained by THI values that exceed the comfort zone for growing cattle $(>80)$. The extent suitability of the ecology of beef cattle farms from the three priority subdistricts is shown in Table 6.

Based on the results of the analysis conducted in Table 6, the sub-districts with the largest land area for the development of beef cattle farms with intensive production systems were Bringin (2,758.86 Ha), Bancak (1,550.08 Ha), and Banyubiru (1,451.2 Ha). The limiting factor in the form of temperature humidity index (THI) or water $\mathrm{pH}$ can be minimized through the engineering design of livestock housing and the provision of materials or neutralizing water acidity solvent (Yani et al., 2007; Sarwanto \& Hendarto, 2011). Cattle with intensive production systems are generally more susceptible to heat stress than cattle with extensive production systems. Efforts that can be done to reduce heat stress in beef cattle include: adding shade around the housing location, install a sprinkle tool or add straw that works to lower the surface temperature of the floor, regulate feed, feed additives, and medicine, etc (Suhaema et al., 2014).

\section{DISCUSSION}

Semarang Regency is a potential area for the development of beef cattle farming because it has abundant natural resources in the form of land for livestock raising and forage production. The mapping activity is based on the determination of leading livestock commodities, and optimization of regional potential can be one of the benchmarks in realizing sustainable development of beef cattle farms. The concept of sustainable development is to meet the needs of the current generation, without sacrificing future generations and this concept has become a reference for welfare in almost all sectors, including the livestock sector (Wasike et al., 2011). The concept of sustainability was widely debated throughout the world over the past few years (De Longe et al., 2016; Keesstra et al., 2016; Rasmussen et al., 2017), not only concerning environmental and social issues, but also discussing economic issues to gain certain market or commodity advantages (Broom et al., 2013; Sabaghi et al., 2016). Sustainability assessment is achieved by evaluating the relative contribution of each of the economic, environmental, and social factors to the overall goal (Astier \& García-Barrios, 2012). Sustainability assessed in this study is economical and environmental sustainability for beef cattle farms.

Economic sustainability was assessed based on the results of the analysis of the leading commodity. The leading livestock commodity in an area was determined based on the comparative advantage (LQ analysis) and competitive advantage (SS analysis). The concept of comparative advantage is economic feasibility. Commodities that have a comparative advantage (LQ>1) show that the commodity (beef cattle) is supported by the existence of adequate natural resources so that the population level is higher than in other regions (Mulyono \& Munibah, 2016). Beef cattle commodity in the base sub-district is a prominent or dominant livestock business compared to the other livestock businesses, so the effort for future development is easier (Yuniar et al., 2016; Mulyono \& Munibah, 2016). On the other hand, the concept of competitive advantage is financial feasibility. Beef cattle commodities are keeping in effective and efficient ways so that they have competitiveness from the aspects of quality, quantity, continuity, and price (Muta'ali, 2015; Mulyono \& Munibah, 2016). The results presented in Table 3 show that the Bringin, Bancak, and Banyubiru sub-districts are regions with a leading commodity of beef cattle. Accordingly, the three sub-districts are prioritized for the development of beef cattle farms in Semarang Regency.

Environmental sustainability for beef cattle farms was assessed based on the results of the carrying capacity analysis and carrying capacity index of forage, and analysis of the suitability of the ecological environment of beef cattle. Carrying capacity is defined as the maximum population that can be supported by an ecosystem from time to time. The carrying capacity of an area is not static, there is a kind of reciprocal relationship between organism and their environments. The carrying capacity of a region can vary for different species and change over time due to various factors (Taiwo \& Feyisara, 2017). Regional carrying capacity for livestock development is the size of the region's ability to support the livelihoods of a number of livestock populations optimally through the role of forage availability. Based

Table 6. Extent of suitability of ecological environment map of beef cattle farms in Bancak, Banyubiru, and Bringin sub-districts

\begin{tabular}{clccccccc}
\hline \multirow{2}{*}{ No } & \multirow{2}{*}{ Subdistrict } & \multicolumn{5}{c}{ Extent of land suitability (Ha) } & \multirow{2}{*}{ Total } \\
\cline { 3 - 7 } & & S1 & S1p & S2 & S2p & S3 & S3p & $1,550.079$ \\
\hline 1 & Bancak & 0 & 40.26 & 0.06 & $1,342.25$ & 0 & 167.51 & 0 \\
2 & Banyubiru & 17.10 & 0 & $1,434.10$ & 0 & 0 & $1,451.2$ \\
3 & Bringin & 0 & 36.01 & 0 & $2,327.42$ & 0 & 395.43 & $2,758.862$ \\
& Total & 17.10 & 76.27 & $1,434.16$ & $3,669.67$ & 0 & 562.94 & $5,760.141$ \\
\hline
\end{tabular}

Note: S1= very suitable, S2= quite suitable, S3= according to marginal, $\mathrm{P}=$ limiting factor in the form of temperature humidity index (THI). 
on the results of the analysis presented in Table 4, it is known that the Bringin, Bancak, and Banyubiru subdistricts have a forage carrying capacity index in the safe category.

The production systems of beef cattle that is often found in Semarang Regency is an intensive production system. Beef cattle are able to show optimal physical conditions if they have superior genetic traits, and are supported by the suitability of their ecological environment (Suhaema et al., 2014). Animal ecology is the study of the interactions between animals and their environments. Environmental factors tend to have a greater effect on the production and productivity of livestock (Sumarto \& Koneri, 2016). Some environmental factors that influence the growth of beef cattle with intensive production systems are: soil type, length of dry season, altitude, slope (Rusmana et al., 2006), temperature and relative humidity, rainfall, and water $\mathrm{pH}$ (Herbut \& Angrecka, 2012; Suhaema et al., 2014; Yuniar et al., 2016; Eirich, 2018).

The results of the analysis in Table 5 show that environmental factors that are limiting the development of beef cattle farms in Semarang Regency are air temperature and humidity, as well as $\mathrm{pH}$ of water used by livestock for drinking. The relationship between the amount of air temperature and humidity is called the Temperature Humidity Index (THI). If THI exceeds the threshold (>80), it can cause stress or heat stress in beef cattle (Eirich, 2018). Long-term heat stress has an impact on increasing drinking water consumption, increasing urine volume, and decreasing feed consumption. The direct effect of heat stress on livestock production causes a decrease in the productivity of beef cattle. This effect is due to the increasing need for livestock maintenance during stress conditions (Berman, 2005). Furthermore, the THI value that exceeds the threshold will decrease the daily body weight gain, increase the depletion of the thickness of meat fat, and increase the potential for disease occurrence, especially in male cattle (Nardone et al., 2010). Hydrogen potential ( $\mathrm{pH}$ ) characterizes the balance between acidic and alkaline solvent in water. If the $\mathrm{pH}$ of drinking water for beef cattle is below the quality standard or acid $(<6,5)$, the water becomes sour and can cause physiological and digestive disorders in livestock. On the other hand, if the $\mathrm{pH}$ of water is too alkaline $(>9)$, the water becomes bitter and causes a decrease in the consumption of drinking water which has an impact on decreasing livestock productivity (Sarwanto \& Hendarto, 2011).

The synthesis of the assessment results of leading commodity, calculation of carrying capacity and carrying capacity index of forage, as well as land suitability assessment, shows that there are three sub-districts (Bringin, Bancak, and Banyubiru) which have high priorities for the development of beef cattle farms in Semarang Regency.

\section{CONCLUSION}

Planning for the development of beef cattle farming with intensive production systems in Semarang Regency is recommended in three sub-districts, namely: Bringin,
Bancak, and Banyubiru. The development of beef cattle farms in the priority sub-districts is expected to increase livestock production and productivity. Governments, communities (cattleman), and the private sector (investors) must coordinate and cooperate with each other so that the development of sustainable beef cattle farms can be achieved.

\section{CONFLICT OF INTEREST}

The authors confirm that there are no conflicts of interest with any financial, personal, or other relationships with other people or organization related to the material discussed in the manuscript.

\section{REFERENCES}

Agus, A. \& T. S. M. Widi. 2018. Current situation and future prospects for beef cattle production in Indonesia - A review. Asian-Australas. J. Anim. Sci. 31:976-983. https://doi. org/10.5713/ajas.18.0233

Ariningsih, E. 2014. Performance of national beef self-sufficiency policy. Forum Penelitian Agro Ekonomi 32:137-156. https://doi.org/10.21082/fae.v32n2.2014.137-156

Astier, M., L. G. Barrios, Y. G. Miyoshi, Carlos. E. G. Esquivel, \& O. R. Masera. 2012. Assessing the sustainability of small farmer natural resource management systems. A critical analysis of the MESMIS program 1995-2010. Ecology and Society 17:25. https://doi.org/10.5751/ES-04910-170325

Atanga, N. L., A. C. Treydte, \& R. Birner. 2013. Assessing the sustainability of different small-scale livestock production systems in the Afar Region, Ethiopia. Land. 2:726-755. https://doi.org/10.3390/land2040726

Berman, A. 2005. Estimates of heat stress relief needs for Holstein dairy cows. Journal Animal Science 83:1377-1384. https://doi.org/10.2527/2005.8361377x

BPS Kabupaten Semarang. 2018. Kabupaten Semarang dalam Angka. Badan Pusat Statistik, Semarang.

Broom, D. M., F. A. Galindo, \& E. Murgueitio. 2013. Sustainable, efficient livestock production with high biodiversity and good welfare for animals. Proc. R. Soc. B. 280: 20132025. https://doi.org/10.1098/rspb.2013.2025

Ciptayasa, I. N., Hermansyah, \& M. Yasin. 2016. Analisis potensi ternak kambing di Kabupaten Lombok Barat. Jurnal Ilmu dan Teknologi Peternakan Indonesia 2:110-115. https://doi.org/10.29303/jitpi.v2i1.20

Darnhofer, I., J. Fairweather, \& H. Moller. 2010. Assessing a farm's sustainability: insights from resilience thinking. Int. J. Agric. Sustain. 8:186-198. https://doi.org/10.3763/ ijas.2010.0480

DeLonge, M. S., A. Miles, \& L. Carlisle. 2016. Investing in the transition to sustainable agriculture. Environ. Sci. Policy. 55:266-273. https://doi.org/10.1016/j.envsci.2015.09.013

Eirich, R. 2018. Beef cattle temperature humidity chart. University of Nebraska. Available at: https://bqa.unl.edu/ heat-stress-resources. [28 December 2018].

Herbut, P. \& S. Angrecka. 2012. Forming of temperature-humidity index (THI) and milk production of cows in the free-stall barn during the period of summer heat. Nim. Sci. Pap. Rep. 30:363-372.

Kadarsih, S. 2004. Performans sapi Bali berdasarkan ketinggian tempat di daerah transmigrasi Bengkulu. Jurnal Ilmu-Ilmu Pertanian Indonesia 6:50-56.

Keesstra, S. D., J. Bouma, J. Wallinga, P. Tittonell, P. Smith, A. Cerda, L. Montararella, J. N. Quinton, Y. Pachepsky, W. H. Putten, R. D. Bardgett, S. Moolenaar, G. Mol, B. Jansen, \& L. O. Fresco. 2016. The significance of soils and 
soil science towards realization of the United Nations sustainable development goals. Soil 2:111-128. https://doi. org/10.5194/soil-2-111-2016

Kementan. 2016. Outlook Daging Sapi. Kementerian Pertanian Republik Indonesia, Jakarta.

Mulyono, J. \& K. Munibah. 2016. Pendekatan location quotient dan shift share analisis dalam penentuan komoditas unggulan tanaman pangan di Kabupaten Bantul. Informatika Pertanian 25:221-230. https://doi.org/10.21082/ ip.v25n2.2016.p221-230

Muta'ali, L. 2015. Teknik Analisis Regional untuk Perencanaan Wilayah, Tata Ruang, dan Lingkungan. Badan Penerbit Fakultas Geografi UGM, Yogyakarta.

Nardone, A., B. Ronchi, N. Lacetera, M. S. Ranieri, \& U. Bernabucci. 2010. Effects of climate changes on animal production and sustainability of livestock systems. Livest. Sci. 130:57-69. https://doi.org/10.1016/j.livsci.2010.02.011

Nuhung, I. A. 2015. Kinerja, kendala, dan strategi pencapaian swasembada daging sapi. Forum Penelitian Agro Ekonomi 33:63-80. https://doi.org/10.21082/fae.v33n1.2015.63-80

Paly, B., A. Natsir, S. Rasyid, \& I. M. Fahmid. 2013. Interconnectivity multi criteria for sustainable development of beef cattle. International Journal of Scientific and Technology Research 2:115-121.

Parmawati, R., Mashudi, A. Budiarto, Suyadi, \& A. S. Kurnianto. 2018. Developing sustainable livestock production by feed adequacy map : A case study in Pasuruan, Indonesia. Trop. Anim. Sci. J. 41:67-76. https://doi. org/10.5398/tasj.2018.41.1.67

Pasandaran, E., Haryono, \& Suherman. 2014. Memperkuat Daya Saing Produk Pertanian. Perspektif Daya Saing Wilayah. IAARD Press, Jakarta.

Rasmussen, L. V., R. Bierbaum, J. A. Oldekop, \& A. Agrawal. 2017. Bridging the practitioner-researcher divide: Indicators to track environmental, economic, and sociocultural sustainability of agricultural commodity production. Glob. Environ. Change 42:33-46. https://doi.org/10.1016/j. gloenvcha.2016.12.001

Rouf, A. A., Daryanto, \& A. Fariyanti. 2014. Daya saing usaha sapi potong di Indonesia: Pendekatan domestic resources cost. Wartazoa 24:97-107. https://doi.org/10.14334/wartazoa.v24i2.1053

Rusmana, N., Atmiyati, \& Ridwan. 2006. Pembuatan peta kesesuaian ekologis untuk ternak ruminansia pada skala tinjau. Pusat Penelitian dan Pengembangan Peternakan, Bogor. pp. 175-178.

Sabaghi, M., C. Mascle, P. Baptiste, \& R. Rostamzadeh. 2016. Sustainability assessment using fuzzy-inference technique (SAFT): A methodology toward green products. Expert Syst. Appl. 56:69-79. https://doi.org/10.1016/j. eswa.2016.02.038

Santos, S. A., H. P. de Lima, Silvia. M. F. S. Massruha, Urbano. G. P. de Abreu, W. M. Tomas, S. M. Salis, E. L. Cardoso, M. D. de Oliveira, Marcia. T. S. Soares, A. dos Santos Jr,
L. O. F. de Oliveira, D. F. Calheiros, S. M. A. Crispim, B. M. A. Soriano, C. O. G. Amancio, A. P. Nunes, \& L. A. Pellegrin. 2017. A fuzzy logic-based tool to assess beef cattle ranching sustainability in complex environmental systems. Journal of Environmental Management 198:95106. https://doi.org/10.1016/j.jenvman.2017.04.076

Saputra, J. I., Liman, \& Y. Widodo. 2016. Analisis potensi pengembangan peternakan sapi potong di Kabupaten Pesawaran. Jurnal Ilmiah Peternakan Terpadu 4:115-123.

Sarwanto, D. \& E. Hendarto. 2011. Analisis kualitas air minum sapi perah rakyat di Kabupaten Banyumas Jawa Tengah. Media Peternakan 13:1-5.

Suhaema, E., Widiatmaka, \& B. Tjahjono. 2014. The regional development of beef cattle based on physical and forage land suitability in Cianjur Regency. Tanah Lingkungan 16:53-60. https://doi.org/10.29244/jitl.16.2.53-60

Sumarto, S. \& R. Koneri. 2016. Ekologi Hewan. Cv. Patra Media Grafindo, Bandung.

Sutanto, A. \& L. Hendraningsih. 2011. Analisis keberlanjutan usaha sapi perah di Kecamatan Ngantang Kabupaten Malang. Gamma 7:1-12.

Syarifuddin, H. 2009. Indeks keberlanjutan integrasi tanaman dengan ternak (crop livestock system) di Kuamang Kuning. Jurnal Ilmiah Ilmu-Ilmu Peternakan XII:41-49.

Taiwo, F. J. \& O. O. Feyisara. 2017. Understanding the concept of carrying capacity and its relevance to urban and regional planning. Journal of Environmental Studies 3:1-5.

Thornton, P. K. 2010. Livestock production: recent trends, future prospects. Philosophical Transactions of the Royal Society B: Biological Sciences. 365:2853-2867. https://doi. org/10.1098/rstb.2010.0134

Tongco, M. D. C. 2007. Purposive sampling as a tool for informant selection. Ethnobotany Research and Applications 5:147-158. https://doi.org/10.17348/era.5.0.147-158

Wasike, C. B., T. M. Magothe, A. K. Kahi, \& K. J. Peters. 2011. Factors that influence the efficiency of beef and dairy cattle recording system in Kenya: A SWOT-AHP analysis. Trop. Anim. Health Prod. 43:141-152. https://doi.org/10.1007/ s11250-010-9666-3

Yani, A., H. Suhardiyanto, R. Hasbullah, \& B. P. Purwanto. 2007. Analisis dan simulasi distribusi suhu udara pada kandang sapi perah menggunakan computational fluid dynamics (CFD). Med. Pet. 30:218-228.

Yuniar, P. S., A. M. Fuah, \& Widiatmaka. 2016. Carrying capacity and priority region for development of beef cattle production in South Tangerang. Jurnal Ilmu Produksi dan Teknologi Hasil Peternakan 4:64-268. https://doi. org/10.29244/jipthp.4.1.264-268

Zakiah, A. Saleh, \& K. Matindas. 2017. Gaya kepemimpinan dan perilaku komunikasi GPPT dengan kapasitas kelembagaan sekolah peternakan rakyat di Kabupaten Muara Enim. Jurnal Penyuluhan 13:133-142. https://doi. org/10.25015/penyuluhan.v13i2.14977 